\title{
The threat from creationism to the rational teaching of biology
}

\author{
ATHEL CORNISH-BOWDEN and MARÍA LUZ CÁRDENAS
}

Laboratoire de Bioénérgétique et Ingénierie des Protéines, CNRS, Marseille, France

\begin{abstract}
Most biologists outside the USA and a few other countries, like Australia and Canada, are under the impression that the threat to the teaching of biology represented by creationism does not concern them directly. This is unfortunately no longer true: the recent growth of creationism, especially in its pseudoscientific manifestation known as "intelligent design", has been obvious in several countries of Western Europe, especially the UK, Germany and Poland, and it is beginning to be noticeable in Brazil, and maybe elsewhere in Latin America. The problem is complicated by the fact that there are not just two possibilities, evolution and creationism, because creationism comes in various incompatible varieties. Turkey is now a major source of creationist propaganda outside the USA, and is especially significant in relation to its influence on Muslim populations in Europe. The time for biologists to address the creationist threat is now.
\end{abstract}

Key terms: education, creationism, intelligent design, fundamentalism, evolution, natural selection.

\section{INTRODUCTION}

Virtually all biologists now accept evolution as a reality that is no longer worth discussing. In the words of Medawar, as quoted by Carroll (2006), "for a biologist, the alternative to thinking in evolutionary terms is not to think at all". This universal acceptance makes it easy for biologists to forget that the situation in the world at large is very different, not only among non-scientists but also to a surprising extent among scientists in nonbiological fields. Even those who are aware of the creationist threat to the rational teaching of biology in the USA often fail to realize that in recent years the problem has spread far beyond the USA, driven in some countries not by Christian fundamentalism but by Islamic fundamentalism. The purpose of this article, therefore, is to make biologists conscious of the existence of a serious threat to their subject, even if they work in countries such as Chile where very little problem is apparent at present, and to emphasize that the moment to plan how to respond to creationism is now.

We should comment at the outset on the fact that nearly all of our references are to web-sites. In a scholarly journal this is far from ideal, because material on the web can and does change without warning or indication from one day to another, and it is often difficult to identify the author or determine the date of last revision. Moreover, there is no certainty -and even in some cases no more than a low probability - that any citation that is correct at the moment of submitting the article will still be correct when it is published and read. However, much as modern teachers might wish their students to read permanent published documents such as books and journal articles, they all know that what students actually read much of the time, whether at high school or in the university, is what they see on their computer screens. Teachers need, therefore, to 
familiarize themselves with the sort of nonsense that is purveyed as biological information on the web, and even if the specific sites that we refer to have changed by the time this article is printed, they remain valid as examples of the sort of material that is in circulation. Biologists who have not examined creationist websites may find it difficult to credit how bad much of the statements offered as biology are, so it may be useful to quote from an article about kangaroos at Conservapedia, set up as "a much-needed alternative to Wikipedia, which is increasingly antiChristian and anti-American" (Anonymous, 2007a):

According to the origins model used by creation scientists, modern kangaroos, like all modern animals, originated in the Middle East and are the descendants of the two founding members of the modern kangaroo baramin that were taken aboard Noah's Ark prior to the Great Flood...

Also according to creation science, after the Flood, kangaroos bred from the Ark passengers migrated to Australia...

Other views on kangaroo origins include the belief of some Australian aborigines that kangaroos were sung into existence by their ancestors during the "Dreamtime" and the evolutionary view that kangaroos and the other marsupials evolved from a common marsupial ancestor which lived hundreds of millions of years ago.

The principal source given for this information is a web page written by the Australian creationist Ken Ham (1996), entitled "Kangaroos, dinosaurs and Eden". Readers should remember that the entries at Conservapedia are frequently updated, so although the quotation is correct at the time of writing it may not survive subsequent editing. In addition, the term baramin is unlikely to be familiar to most biologists: it refers to an attempt to place the biblical notion of a "kind" of animal on a scientific footing.

\section{CREATIONISM AND BIOLOGY IN THE USA}

The creationist threat to biology in the USA is so well known that it requires little discussion here, but it is worthwhile to correct a widespread misapprehension. The trial of John T. Scopes in 1925 is often regarded as a de facto victory for the rational teaching of biology in the USA, because, although the fundamentalists won the case, their spokesmen made themselves so ridiculous in the process that other states were discouraged from proposing laws similar to the Tennessee law that Scopes had violated. This is the conventional view of the story, but it gives a wrong reason for the lack of conflict in the USA for a generation after 1925: this is better explained by the fact that there was essentially no teaching of evolution in schools in the USA during this period, and consequently no laws to forbid it were perceived as necessary. This only changed after the launching of the Sputnik by the USSR in 1957, which made it clear that the gap in scientific achievement between the USA and the USSR was much narrower than had been thought, so that serious attention needed to be given to the teaching of science, including biology, in schools.

The reappearance of evolution as an essential part of the teaching of biology brought with it a reawakening of vehement opposition to it from Christian fundamentalists. Starting with Arkansas in 1981, several states have proposed laws that would require "balanced" teaching of biology, with "creation science" taught in secondary schools on an equal basis with evolution. One may suspect that this is just a delaying tactic, and that once the battle for equal time is won the creationists will proceed to their real objective of eliminating the teaching of evolution altogether. As quoted by Stephen Jay Gould (1984), the anti-evolution activist Paul Ellwanger made this quite clear in a letter to a state legislator. The wording of the Arkansas law is worth noting: as part of the state's efforts "to protect academic freedom" it will "require balanced treatment of creation science and evolution science in public schools" - a novel 
interpretation of the idea of academic freedom to mean that teachers must be forced to teach material that they do not believe in!

By 2006, the American Society for Biochemistry and Molecular Biology had become sufficiently concerned to organize a symposium on "Teaching the Science of Evolution under the Threat of Alternative Views" at its annual meeting, to complement a symposium on "Current Themes in Molecular Evolution" during the same meeting. Speakers at the former of these emphasized that "anti-evolution activity is nationwide," but, as we shall discuss, it is now far more than just "nationwide".

\section{CREATIONISM AND BIOLOGY IN EUROPE}

\section{The UK}

In April 2006 the Royal Society (effectively the Academy of Sciences of the UK) issued a statement that evolution is "recognised as the best explanation for the development of life on Earth from its beginnings and for the diversity of species" and that it is "rightly taught as an essential part of biology and science courses in schools, colleges and universities across the world" (Anonymous, 2006a). Why should such a statement have appeared necessary or desirable in the UK in 2006, given that most educated people in the UK suppose that the academic arguments were essentially settled by the end of the 19th Century? The case of a state-supported school in Gateshead, a town in the North of England, illustrates the answer to this question. A lecture by Steven Layfield, Head of Science at Emmanuel College, was at one time posted on the site of the Christian Institute (Anonymous, $2000)$; it was subsequently removed "temporarily" from there after its content had been criticized in a newspaper, but is preserved on another site (Brown, 2006). It expresses very surprising opinions for the head of science in a school: "If, as Jesus clearly taught, the Bible really is the Word of God -and the internal evidence is overwhelming- true Science will always agree with it". In other words, the Bible provides the criterion by which the truth or otherwise of scientific hypotheses must be assessed.

The British Magazine The New Humanist has reported on a discussion in Parliament about Emmanuel College and other similar schools (Wheen, 2003). When the Prime Minister was asked if he was "happy to allow the teaching of creationism alongside Darwin's theory of evolution in state schools", he replied merely that "in the end a more diverse school system will deliver better results for our children". This reply should be carefully noted by anyone who is tempted to believe that political leaders can be trusted to protect academic standards, and we shall show below that the lack of concern of political leaders for academic standards is no less evident in other countries, such as Germany, Poland and Brazil. The consequence in the UK may be judged from the results of a survey published in the British newspaper The Guardian (Anonymous, 2006b) in August 2006: more than 12\% of UK students questioned preferred creationism to any other explanation of human origins, and another $19 \%$ favoured the theory of "intelligent design". Hardly a week now passes without further evidence of a sustained and concerted attack on biology teaching in the UK; in September 2006, for example, an organization calling itself Truth in Science distributed its resource pack of creationist propaganda to the head of science of every secondary school in the UK (Anonymous, 2006c).

\section{Germany}

The situation in Germany is certainly no better than it is in the UK, and may be worse. Creationist activity is very evident in Germany (Anonymous, 2007b), and creationist texts of high technical quality are readily available for children and students (Anonymous, 2006d). Creationist teaching in two schools in Giessen, in the State of Hesse, was discussed in a documentary film on the Franco-German television channel Arte, and after it had been broadcast the Education Minister of 
the State of Hesse, Karin Wolff, said that she believed "biblical creation theory should be taught in biology class as a theory, like the theory of evolution" (Anonymous, 2006e). Again, the conclusion must be that biologists cannot rely on politicians to protect academic standards.

\section{Poland}

The Deputy Education Minister of Poland, Miroslaw Orzechowski, said in October 2006 that "The theory of evolution is a lie. It is an error we have legalized as a common truth" . Reporting this, Graebsch (2006) noted that Maciej Giertych, the father of the Polish Minister of Education and himself a Member of the European Parliament, is lobbying for obligatory inclusion of creationism in Polish biology curricula. In subsequent correspondence Giertych (2006) denied that his motivation was religious, but he undermined this claim by adding that "there seems to be total ignorance of new scientific evidence against the theory of evolution. Such evidence includes ... formation of geological strata sideways rather than vertically, archaeological and palaeontological evidence that dinosaurs coexisted with humans, a major worldwide catastrophe in historical times, and so on". Giertych gave no source for this claim, and in fact no such "evidence" can be found in the scientific literature; it comes instead from sources that are inspired by religious motives. In a later letter the Director of the Institute of Dendrology (which Giertych had given as his address) pointed out that although she respected his rights to express his views they were not endorsed by the institute, and in her opinion creationism had no basis in science and should not be regarded as scientific (Lorenc-Plucińska, 2006).

\section{France}

In many ways the degree of creationist infiltration of education in France appears less serious than in the other countries we have mentioned. Nonetheless, as described in the book by Arnould (2007), a Dominican theologian, France has a home- grown creationist movement, the Cercle d'Étude Historique et Scientifique, or CESHE. This was founded in 1980 and actively promotes the same ideas as American creationists, but also displays at times a remarkable degree of hostility not only towards established science but also towards the hierarchy of the Roman Catholic Church. A spokesman for the CESHE, for example, describes the Pontifical Academy as "composed of twothirds evolutionist atheist scientists, who sabotage Christianity", and suggests that the Pope (John-Paul II) would do better "to consult his friend Professor Gyertich of the Polish Academy of Sciences, who is creationist". (Despite the different spelling this is probably the same Giertych as mentioned above.) However, the social and political climate of France is very different from that of the USA, and there is little to suggest that fringe groups such as CESHE have a significant influence; the appearance of the Atlas of Creation (see below) in France in early 2007 caused more of a stir than CESHE has produced in a quarter of a century of activity.

\section{Other parts of Western Europe}

Current creationist activity is also evident in Belgium, The Netherlands and Scandinavia. Even if it appears not yet to have reached the proportions noted in the UK, Germany or Poland, there is little ground for complacency, in view of the rapid deterioration elsewhere.

\section{Turkey}

Turkey may well constitute the most important source of creationist propaganda outside the USA, and it certainly explains much of the success of creationists in attracting support from Muslim students in the UK, Germany and France. Large meetings in modern congress centres with high attendance (Anonymous, 1998) illustrate the high degree of financial support, as does extensive publication of creationist texts (Anonymous, 2005): the book Evolution Deceit is available not only in Turkish and English, but also in French, 
German, Spanish, Italian, Russian and Arabic, and circulated in many countries, definitely including Argentina, and possibly others in Latin America (Anonymous, 2007c). Recently the profusely illustrated and expensively produced Atlas of Creation from the same source (Anonymous, 2007d) has been distributed in several languages free of charge to teachers, schools and universities in different countries. One quotation from the Introduction will suffice to illustrate its academic level:

The fossil record is perhaps the most important evidence that demolishes the theory of evolution's claims. Fossils reveal that life forms on Earth have never undergone even the slightest change and have never developed into one another. Examining the fossil record, we see that living things are exactly the same today as they were hundreds of millions of years ago - in other words, that they never underwent evolution.

\section{CREATIONISM IN SOUTH AMERICA}

There is little at present to suggest a creationist surge in most of Latin America, but in Brazil there is evidence of a threat similar to that in Western Europe. As reported in the Brazilian magazine Época, the state of Rio de Janeiro has instituted classes in state-supported schools in which the evolution of species is questioned, and the Governor of the State said in an interview that she did not believe in the evolution of species, which was just theory (Martins and França, 2004).

\section{CREATIONISM AND RELIGION}

Religious fundamentalists, whether Christian or Muslim, claim that the theory of evolution is essentially atheistic and hostile to religious belief. Atheist biologists do exist, of course, as illustrated by the recent book The God Delusion by Richard Dawkins (2006), but that is not all the same as claiming that belief in evolution is incompatible with religion. The view of the more moderate religious leaders was cogently summarized by the late Pope JohnPaul II in a statement published in L'Osservatore Romano in 1996, quoted by Carroll (2006):

Fresh knowledge has led to the recognition that evolution is more than a hypothesis. It is indeed remarkable that this theory has been progressively accepted by researchers, following a series of discoveries in various fields of knowledge. The convergence, neither sought nor fabricated, of the results of work that was conducted independently is in itself a significant argument in favour of this theory.

The Pope's statement is important in that it gives the real reasons for the universal acceptance of evolution by biologists: not that evolution is in itself a "religion" -a claim advanced by some creationists in the USA in the hope of perverting the constitutional separation between religion and government to their own ends- but that it is the result of a great accumulation of data pointing in a consistent direction. The point was succinctly put by the great evolutionist Theodosius Dobzhansky (1973) in the title of an article in American Biology Teacher: "Nothing in biology makes sense except in the light of evolution". Biologists believe in evolution not because of any "religious" commitment to it but because of overwhelming evidence for it.

The title of Dobzhansky's article is frequently quoted, but the article itself, which contains some additional important points, is less well known. It opens by discussing a Muslim fundamentalist's attack on the Copernican view of the solar system. Although in 1973 most biologists thought that the major threat to rational science teaching came from Christian fundamentalism, it may be that even then Dobzhansky realized that other varieties of fundamentalism needed to be taken into account. He went on to declare that

I am a creationist and an evolutionist. Evolution is God's, or Nature's, method 
of creation. Creation is not an event that happened in $4004 \mathrm{BC}$; it is a process that began some 10 billion years ago and is still under way.

His reference to God in this quotation is much more than empty rhetoric, as throughout his life he was a practising Russian Orthodox Christian, for whom the idea that evolution was incompatible with his religious faith was absurd.

\section{"TWO MODELS"}

Creationists frequently demand "fairness" and "equal time" for their ideas in education, basing their demands on the claim that just "two models" are possible. Manthei (1998), for example, makes this claim explicitly when he discusses "the direct conflict between evolution and the Bible" in which "only one system can be correct" [emphasis in the original].

This claim, however, is false. It is by no means true that creationists are all in agreement with one another, or that their disagreements are at a more superficial level than the (legitimate) arguments that occur between real scientists. We can probably set aside the most extreme views, such as the idea that the earth is flat (Schadewald, 1980), or the claim that belief in a heliocentric solar system set the stage for most of the evils that the world has seen in the past few centuries (Babinski, 2005), because these are now held by very few people. This still leaves a wide range of incompatible varieties of creationism (Figure 1), ranging from youngearth creationists, who believe that the earth is no more than a few thousand years old (Mortensen, 2004), to progressive creationists (Anonymous, 2007e), who accept that the universe may be millions of years old but believe in miraculous interventions "guiding" the appearance of new species. Moreover, although these various groups may try to present the appearance of unity when confronting conventional biology, they do not do so when confronting one another. Young-earth creationists, for example, say that "The Intelligent Design movement is such a mixture of agnostics and theists of great theological variety that it can never be concerned about faithfulness to the true God and His Word" (Mortensen, 2004) [emphasis in the original]; for their part progressive creationists complain about myths about them "circulated among Christians" (Anonymous, 2007e) (not, we should note, myths circulated by scientists), and they accuse Ken Ham, a well known young earth creationist (Ham, 1996), of "showing his willful ignorance of old earth belief" (Neyman, 2005).

Flat earthism

Young earth

Geocentrism

Young earth creationism

Gap creationism

Day-age creationism

Progressive creationism

Evolutionary creationism

Theistic evolution

Agnostic evolutionism

Materialist evolutionism

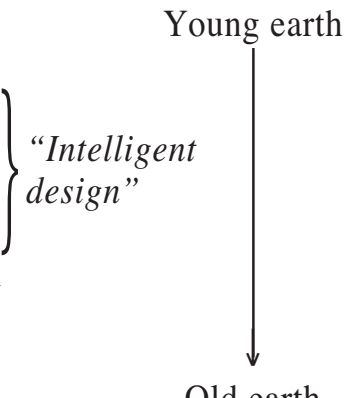

Figure 1: Range of creationist views. The figure shows a classification by Eugenie Scott (2005) of the wide variety of views that exist about biology and geology, ranging from those who believe in a flat earth no more than a few thousand years old to those who believe in an earth several billion years old and reject any form of religious explanation for it. Note that the "intelligent design" movement is not uniform, but encompasses a wide range of views within the creationist range.

\section{SCIENTISTS OPPOSED TO EVOLUTION}

In an effort to show that "creation science" is science, its advocates have assembled a list of scientifically qualified people willing to sign the following declaration:

I am skeptical of claims for the ability of random mutation and natural selection to account for the complexity of life. Careful examination of the evidence for Darwinian theory should be encouraged.

Notice that this declaration is mild in tone: few legitimate scientists would have 
difficulty in putting their names to the second sentence; even the first sentence is objectionable more for its implications than for what it specifically says. Not surprisingly, therefore, a little more than 100 people were quickly found who would sign it (Edwards, 2001). What is more surprising is that only about a third of them have even modest claims to expertise in biology, and five of them work at Biola University (formerly the Bible College of Los Angeles), not an institution noted for its research in biology. To illustrate the futility of assembling lists of people (rather than lists of cogent arguments), as if scientific questions were decided democratically, the National Center for Science Education has compiled its own list of scientists called Steve (in honour of Stephen J. Gould) willing to sign a much more forthright statement of support for evolution:

Evolution is a vital, well-supported, unifying principle of the biological sciences, and the scientific evidence is overwhelmingly in favor of the idea that all living things share a common ancestry. Although there are legitimate debates about the patterns and processes of evolution, there is no serious scientific doubt that evolution occurred or that natural selection is a major mechanism in its occurrence. It is scientifically inappropriate and pedagogically irresponsible for creationist pseudoscience, including but not limited to "intelligent design", to be introduced into the science curricula of our nation's public schools.

This list rapidly exceeded the total of 100 initially claimed by the creationists, and now, after several years, contains nearly 800 names (Anonymous, 2007f). More important, however, is the extremely meagre nature of the creationists' list, which contains only three names with any prominence at all, Michael Behe, William Dembski and Jonathan Wells. Of these, only Behe has any serious claim to be regarded as a biologist, and we shall return to him later. Dembski has no publications at all in refereed journals of biology. Wells has very few, and although one of these (Rowning et al., 1997) is in a major journal it has no obvious relevance to his creationist beliefs. He has, however, succeeded in publishing a creationist article in a refereed journal (Wells, 2005), though one must remember, of course, that not all refereed journals adhere to the same standards of refereeing.

\section{"INTELLIGENT DESIGN"}

As noted above, young-earth creationists complain that "intelligent design" encompasses a great variety of different sorts of belief, and in this respect (if in few others) they are right; it does. It cannot be ignored, however, because it provides almost the only justification for claiming that "creation science" has a scientific basis. Phillip Johnson, the originator of "intelligent design", is a retired professor of law at the University of California at Berkeley, and has no scientific credentials, but the idea has been given some credibility by Michael Behe, who tries to justify "intelligent design" in terms of "irreducible complexity", the idea that living organisms depend on numerous systems (like blood clotting) that can only work if all of the components are simultaneously present and functional. Behe does have some legitimate publications in relevant areas of biochemistry, such as studies of sickle-cell haemoglobin (Behe and Englander, 1979), DNA structure (Luthman and Behe, 1988) and protein folding (Behe et al., 1991), and his book Darwin's Black Box (Behe, 1998) is widely cited by people desperate to find a book by a real biologist that attacks the idea of evolution. For example, the British organization Truth in Science mentioned earlier calls it "an excellent and essential introduction to the scientific theory of intelligent design" (Anonymous, 2007g). Behe himself modestly describes his work as "so unambiguous and so significant that it must be ranked as one of the greatest achievements in the history of science. The discovery rivals those of Newton and Einstein, Lavoisier and Schrödinger, Pasteur, and Darwin”. 
As many reviewers of Darwin's Black Box have noted, Behe (like Johnson) is careful never to name the Designer supposedly responsible for the design that we see all around us in the biological world, in this way trying to support the claim that the motivation is purely scientific and that religion has nothing to do with it. Nonetheless, only the most naive readers are likely to be left in any doubt about which Designer they have in mind. A point of more importance for biochemists is that Behe claims throughout his book that his conclusions follow necessarily from the study of biochemistry, giving the impression to non-biochemist readers (though stopping short of the outright lie of saying so in so many words) that anyone trained in biochemistry will agree. This is so far from the truth that his own academic department at Lehigh University have taken the almost unprecedented step of posting a statement on their web site describing him as the "sole dissenter" from the position of the departmental faculty, "unequivocal in their support of evolutionary theory" (Brace, 2007).

The most serious fault in the book is the pervasive confusion that it makes and encourages between the origin of life and evolution. Charles Darwin did have some suggestions to make about the origin of life, but his fame rests not on these but on the theory of natural selection, which concerns not the origin of life but its subsequent evolution. It is perfectly possible to think that there remain serious difficulties in understanding how the first organisms came to exist, but at the same time to think that natural selection offers an almost complete explanation of evolution. Indeed, that would be the position of most biologists: hardly anyone considers that the origin of life is well understood (and even the very definition of life is far from being a matter of general agreement, as we discuss elsewhere (Cornish-Bowden et al., 2007), but nearly everyone considers that natural selection is in general correct. In Behe's book, however, the ideas of irreducible complexity are presented as if they were an argument against natural selection, when they are nothing of the kind. Insofar as they are worth bothering with at all, they draw attention to some of the points that a theory of the origin of life will need to explain. For the question that most exercises creationists, the degree of relationship between humans and apes, irreducible complexity has no relevance whatsoever. Behe's example of blood clotting operates in exactly the same way in chimpanzees and humans, and has precisely nothing to say about whether or when chimpanzees and humans had a common ancestor.

In his book Behe claims that "there has never been a meeting, or a book, or a paper on details of the evolution of complex biochemical systems". However, the evolution of the Krebs cycle has been thoroughly discussed (Meléndez-Hevia et al., 1996), and forms an important theme in Kenneth Miller's book Finding Darwin's God (Miller, 1999), and the more general question of the evolution of biochemical pathways and structures is discussed extensively in another book by one of us (Cornish-Bowden, 2004). Notice that Behe left himself an escape clause by not defining "complexity", so that he could dismiss the Krebs cycle as not fitting his definition, and say that "none of the papers [Miller] cites deals with irreducibly complex systems" (Behe, 2000). However, if we take "complex" to mean what any reasonable biochemist would take it to mean, the claim that the evolution of complex biochemical systems is never discussed in the literature or at meetings is clearly false.

In a passage that seems to have escaped the notice of people who think that Behe has disproved Darwinian evolution he says that he finds the idea of "common descent (that all organisms have a common ancestor) fairly convincing". He also says that "on a small scale, Darwin's theory has triumphed... but it is at the level of macroevolution ... that the theory evokes skepticism". A similar idea can be found in the writings of a much more distinguished thinker (Ratzinger, 2003):

Within the teaching about evolution itself, the problem emerges at the point of transition from micro- to macro- 
evolution, on which point Szathmáry and Maynard Smith, both convinced supporters of an all-embracing theory of evolution, nonetheless declare that: "There is no theoretical basis for believing that evolutionary lines become more complex with time; and there is also no empirical evidence that this happens".

This quotation appears at odds with the various books and articles by Szathmáry and Maynard Smith, as explaining macroevolution was the central objective of their collaboration, and it seems likely that the author was misled by Behe's book. The problem with the quotation is not that it is wrong, but that it is incomplete (Szathmáry and Maynard Smith, 1995):

There is no theoretical reason to expect evolutionary lineages to increase in complexity with time, and no empirical evidence that they do so. Nevertheless, eukaryotic cells are more complex than prokaryotic cells, animals and plants are more complex than protists, and so on. This increase in complexity may have been achieved as a result of a series of major evolutionary transitions. These involved changes in the way information is stored and transmitted.

John Maynard Smith probably never saw this reference to his work before he died, but Eörs Szathmáry (2006) has discussed it.

\section{CONCLUSIONS}

In this article we have given comparatively little attention to the emptiness of the arguments against evolution, because this is thoroughly dealt with elsewhere, most recently in the book Evolution vs. Creationism (Scott, 2005), but also in an older but very scholarly book Science and Creationism (Montagu, 1984), and there is also a brief but thorough account in a recent book (Carroll, 2006). We have been more concerned with two points that are hardly mentioned, if at all, by commentators in the USA: creationism now represents a major threat to the rational teaching of biology not only in the USA and in other countries like Canada and Australia that have long had active creationist movements, but throughout the world; in addition, outside the USA it is no longer true that the major threat is coming from Christian fundamentalism, as a substantial amount of propaganda is now produced in Turkey and distributed to Muslims in Western Europe and in many countries elsewhere. Even if the threat has not yet become serious in countries such as Chile, there is no certainty that it will not become one in the future: this is already happening in Brazil, and the time for biologists to think about how to address it is now, not in a few years' time.

\section{REFERENCES}

ANONYMOUS (1998) Evrim teorisinin çoküsü yaratılıs gerçegi uluslararası konferenanslar serisi-I. http:// www.bilimarastirmavakfi.org/evrim istanbul1 html

ANONYMOUS (2000) The Christian Institute. http:// www.christian.org.uk

ANONYMOUS (2005) The "mechanism" behind intelligent design. http://www.islamic-world .net/intldes.php

ANONYMOUS (2006a) Royal Society statement on evolution, creationism and intelligent design. http:// www.royalsoc. ac .uk/news .asp? $i d=4298$

ANONYMOUS (2006b) How did we get here? http:// education.guardian.co.uk/higher/news/story/ $0,, 1844478,00 . h t m l$

ANONYMOUS (2006c) Resource Pack. http:// www.truthinscience.org.uk/site/content/view/43

ANONYMOUS (2006d) Publikationen. http://www.wortund-wissen.de/publikationen.html

ANONYMOUS (2006e) German scientists concerned about rise in creationist belief. http://www.dw-world.de/dw/ article/0,2144,2222454,00.html

ANONYMOUS (2007a) Kangaroo. http:// Www.conservapedia.com/Kangaroo

ANONYMOUS (2007b) Wissenschaft im Evangeliumsnetz. http://www.evangelium.de/wissenschaft.0.html

ANONYMOUS (2007c) The evolution deceit: the scientific collapse of Darwinism and its ideological background. ht t p : / / ww w harunyahya.com/evolution specialpreface.php

ANONYMOUS (2007d) Atlas of creation. http:// www.harunyahya.com/books/darwinism/atlas_creation/ atlas_creation_01.php

ANONYMOUS (2007e) Providing powerful new reasons from science to believe in Christ. http:// WWw.reasons.org/about/

ANONYMOUS (2007f) Steve-o-meter. http:// www.ncseweb.org/resources/articles/meter.html

ANONYMOUS (2007g) Darwin's Black Box. http:// www.truthinscience.org.uk/site/content/view/137/57/

ARNOULD J (2007) Dieu versus Darwin, Albin Michel, Paris

BABINSKI ET (2005) The Evils of Copernicanism. http:// www.edwardtbabinski.us/babinski/copernicanism.html 
BEHE MJ (1998) Darwin's Black Box: the Biochemical Challenge to Evolution, The Free Press, New York

BEHE MJ (2000) Irreducible complexity and the evolutionary literature. http://www.trueorigin.org/ behe04.asp

BEHE MJ, ENGLANDER WS (1979) Quantitative assessment of the noncovalent inhibition of sickle hemoglobin gelation by phenyl derivatives and other known agents. Biochemistry 18: 4196-4201.

BEHE MJ, LATTMAN EE, ROSE GD (1991) The proteinfolding problem: the native fold determines packing, but does packing determine the native fold? Proc Natl Acad Sci USA 88: 4195-4199.

BRACE M (2007) Department position on evolution and "intelligent design". http://www.lehigh.edu/ inbios/ news/evolution.htm

BROWN A (2006) What the Christian Institute really believes. http://www.darwinwars.com/lunatic/liars/ layfield.html

CARROLL SB (2006) The Making of the Fittest, pp. 215247, W. W. Norton and Co., New York

CORNISH-BOWDEN A (2004) The Pursuit of Perfection, Oxford University Press, Oxford

CORNISH-BOWDEN A, CÁRDENAS ML, LETELIER JC, SOTO-ANDRADE J (2007) Beyond reductionism: metabolic circularity as a guiding vision for a real biology of systems. Proteomics 7: 839-845.

DAWKINS R (2006) The God Delusion, Bantam Press, London

DOBZHANSKY T (1973) Nothing in biology makes sense except in the light of evolution Amer Biol Teacher 35: 125-129

EDWARDS M (2001) 100 Scientists, National Poll Challenge Darwinism. http://www .reviewevolution.com/ press/pressRelease_ 100Scientists.php

GIERTYCH M (2006) Creationism, evolution: nothing has been proved. Nature 444: 265

GOULD SJ (1984) Creationism: genesis vs. geology, in Science and Creationism (ed. MONTAGU A), pp. 126135, Oxford University Press, Oxford

GRAEBSCH A (2006) Polish scientists fight creationism. Nature 443: 890-891.

HAM K (1996) Kangaroos, dinosaurs and Eden. http:// biblicalstudies.qldwide.net.au/cs-kangaroos_dinosaurs_ and_eden.html

LORENC-PLUCINSKA G (2006) Creationist views have no basis in science. Nature 444: 679

LUTHMAN K, BEHE MJ (1988) Sequence dependence of DNA structure. The $\mathrm{B}, \mathrm{Z}$, and A conformations of polydeoxynucleotides containing repeating units of 6 to 16 base pairs. J Biol Chem 263: 15535-15539.

MANTHEI D (1998) Two worldviews in conflict. Creation 20: $26-27$

MARTINS E, FRANÇA V (2004) Rosinha contra Darwin h t t p : // revis tae poca.globo.com/Epoca/ 0,6993,EPT731549-1664-1,00.html

MELENDEZ-HEVIA E, WADDELL TG, CASCANTE M (1996) The puzzle of the Krebs citric acid cycle: assembling the pieces of chemically feasible reactions, and opportunism in the design of metabolic pathways during evolution. J Mol Evol 43: 293-303.

MILLER KR (1999) Finding Darwin's God: a scientist's search for common ground between God and evolution, Cliff Street Books, New York

MONTAGU A (ed., 1984) Science and Creationism, Oxford University Press, Oxford

MORTENSEN T (2004) Philosophical naturalism and the age of the earth: are they related? http:// ww w.ans wersingenesis.org/docs $2004 /$ naturalismChurch.asp

NEYMAN G (2005) Creation Science Commentary - Ham Can't Tell the Simple Truth! http:// www.answersincreation.org/commentary/ham_truth_ csc12.htm

RATZINGER JC (2003) Glaube - Wahrheit - Toleranz. Das Christentum und die Weltreligionen, Herder; English translation by Henry Taylor, Truth and Tolerance: Christian Belief and World Religions, Ignatius Press, 2004

ROWNING BA, WELLS J, WU M, GERHART JC, MOON RT, LARABELL CA (1997) Microtubule-mediated transport of organelles and localization of $\beta$-catenin to the future dorsal side of Xenopus eggs. Proc Natl Acad Sci USA 94: 1224-1229.

SCHADEWALD RJ (1980) The Flat-out Truth: Earth Orbits? Moon Landings? A Fraud! Says This Prophet. http://www.lhup.edu/ DSIMANEK/fe-scidi.htm

SCOTT EC (2005) Evolution vs. Creationism, University of California Press, Berkeley

SZATHMARY E (2006) Birds as aeroplanes: remembering John Maynard Smith. Biol Theory 1: 84-86.

SZATHMARY E, MAYNARD SMITH J (1995) The major evolutionary transitions. Nature 374: 227-232.

WELLS J (2005) Do centrioles generate a polar ejection force? Riv Biol 98: 71-86.

WHEEN F (2003) Crystal balls, primal screams. http:// www.newhumanist.org.uk/volume 118 issue 2 comments.php?id=8_0_2_0_C 